Click www.researchjournal.co.in/online/subdetail.html to purchase.

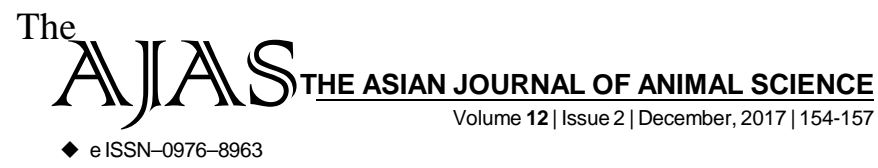

DOI : 10.15740/HAS/TAJAS/12.2/154-157

Visit us | www researchjournal.co in

RESEARCH ARTICLE........

\title{
Preparation of dried gold spotted anchovy (Coilia dussumieri)
}

DEEPA D. MADATHIL, JITESH B. SOLANKI AND SUSHRI SUBHASINI BEHERA

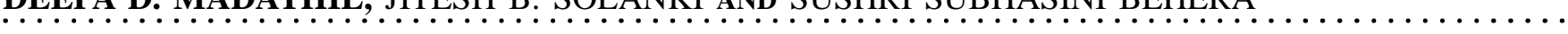

Author for Corresponding DEEPA D. MADATHIL Department of Fish Processing Technology, College of Fisheries Science, Junagadh Agricultural University, VERAVAL (GUJARAT) INDIA

Email : deepamadathil.d@ gmail.com

See end of the article for Coopted authors'
ABSTRACT...... A method of drying gold spotted anchovy (Coilia dussumieri) was develpoed. The physical characteristics and proximate composition of fresh fish and dried fish has been studied. The environmental parameters during the drying of fish was also been evaluated. It is highly rich in protein, which is very important for human consumption. Good market demand of packaging of dried gold spotted anchovy as compared to local dried product available in market.

KEY WORDS...... Coilia dussumieri, Gold spotted anchovy, Drying

HOW TO CITE THIS ARTICLE - Madathil, Deepa D., Solanki, Jitesh B. and Behera, Sushri Subhasini (2017). Preparation of dried gold spotted anchovy (Coilia dussumieri). Asian J. Animal Sci., 12(2): 154157. DOI : 10.15740/HAS/TAJAS/12.2/154-157.

ARTICLE CHRONICLE - Received : 28.10.2017; Revised : 13.11.2017; Accepted : 26.11.2017 